\title{
Above- and belowground distribution of dry matter and carbon biomass of Atlantic beech (Fagus sylvatica L.) in a time sequence
}

\author{
Sandrine HUET ${ }^{\mathrm{a}}$, Françoise FORGEARD ${ }^{\mathrm{a}}$, Claude NYS ${ }^{\mathrm{b} *}$ \\ a Équipe Dynamique des Communautés, UMR CNRS ECOBIO 6553, Université de Rennes 1, \\ Complexe Scientifique de Beaulieu, 35042 Rennes Cedex, France \\ b Unité Biogéochimie des Écosystèmes Forestiers, Inra - Centre de Nancy, 54280 Champenoux, France
}

(Received 2 May 2003; accepted 4 July 2003)

\begin{abstract}
Forests could play an important role in limiting atmospheric $\mathrm{CO}_{2}$ levels. The aims of this work were to (1) produce data about the quantities of carbon stored in beech and in its different aerial and underground components, in five stands in a time sequence; (2) to clarify quantitatively and qualitatively the fate of carbon stocks during forest exploitation. The methods used to determine the different biomass components, and the variability of carbon levels related to the components and tree-age, are discussed. Total (aerial and underground) woody dry matter and carbon biomass increased from $24 \mathrm{t} / \mathrm{ha}$ to $492 \mathrm{t} / \mathrm{ha}$ and from $11 \mathrm{t} / \mathrm{ha}$ to $232 \mathrm{t} / \mathrm{ha}$ respectively from the 8-year-old stage to the 145 year-old stage. The carbon is mainly stored in the trunk. The underground biomass contribution is considerable: $11 \%$ at the 145 -year-old stage. The amount of carbon exported during the time sequence, further thinnings and the clear felling, was estimated to be 355 t/ha, that of the wood left on the ground $52 \mathrm{t} / \mathrm{ha}$ and in the roots $65 \mathrm{t} / \mathrm{ha}$.
\end{abstract}

carbon / biomass / beech / time sequence / distribution / exportation

Résumé - Compartimentation des biomasses aériennes et racinaires, en matière sèche et carbone, dans une chrono-séquence de hêtraie (Fagus sylvatica L.) atlantique. Les forêts joueraient un rôle important dans la limitation de l'élévation de la teneur en $\mathrm{CO}_{2}$ atmosphérique. Les objectifs de notre étude sont (1) d'apporter des données sur les quantités de carbone stocké dans le hêtre et ces différents (sous-) compartiments (aériens et souterrains), pour cinq peuplements d'une chronoséquence; (2) de préciser quantitativement et qualitativement le devenir de ces stocks lors des exploitations forestières. Les aspects méthodologiques pour déterminer les biomasses des différents (sous-) compartiments, et la variabilité de la teneur en carbone en fonction du (sous-)compartiment et de l'âge de l'arbre, sont discutés. Les biomasses ligneuses totales (aériennes et souterraines) en matière sèche et en carbone évoluent respectivement de 24 t/ha à 492 t/ha et de 11 t/ha à 232 t/ha depuis le stade 8 ans au stade 145 ans. Le carbone est stocké majoritairement dans le tronc. La contribution de la biomasse souterraine n'est pas négligeable : $11 \%$ au stade 145 ans. La quantité de carbone exporté au cours de la chronoséquence, suite aux éclaircies et à l'exploitation finale, est évaluée à 355 t/ha, celle du bois laissé sur sol à 52 t/ha, et celle des racines à 65 t/ha.

biomasse / carbone / hêtre / chronoséquence / compartimentation / exportation

\section{INTRODUCTION}

Atmospheric $\mathrm{CO}_{2}$ levels have increased by about $30 \%$ between the era of the industrial revolution and the present day [3]. This increase was due to the combustion of fossil fuels $(6 \mathrm{Gt} / \mathrm{yr})$ and deforestation $(2 \mathrm{Gt} / \mathrm{yr})$ [23]. The increase in this principal greenhouse effect gas, amongst other gases, has contributed to global warming. In France, $\mathrm{CO}_{2}$ represents about half of the greenhouse gases, followed by methane, the CFCs (17\% each) and $\mathrm{NO}_{2}(7 \%)$ [8]. The countries which recognise the danger of global warming met in Rio (1992), Helsinki (1993) and Kyoto (1997). During these meetings, the role that forests could play in limiting atmospheric $\mathrm{CO}_{2}$ was discussed, as forests and forest soils have an enormous capacity for stocking or releasing carbon. It was agreed that detailed inventories of carbon stocks and carbon budgets in forest ecosystems were necessary for carbon management [14, 22].
In most studies, estimates of dry matter and carbon stocks at the tree level only take the trunk, the branches, and sometimes the roots into account, whereas a tree consists of components which are anatomically and industrially different. The future of the various parts or sub-components may be very different. Annual litterfall includes diverse material (leaves, fruits, wood, ....). Anthropic activity during thinning or clear cutting produce dead wood supplies on the ground, organic matter supplies into the soil coming from roots, and wood outputs for various commercial uses. All these different components decompose naturally or are destroyed by man at various speeds. In other words, the carbon stored in these components may return into the atmosphere slowly or very quickly [3].

Variability in the stocks depending on tree species is less well known. In the literature, there is little data about dry matter (biomass) and carbon in beech, in spite of the fact that beech (and oak) is the climax species for a large number of regions

\footnotetext{
* Corresponding author: nys@ nancy.inra.fr
} 
Table I. Main forestry characteristics for each stand.

\begin{tabular}{|c|c|c|c|c|c|c|}
\hline $\begin{array}{l}\text { Age in } 1995 \\
\text { (years) }\end{array}$ & Name & $\begin{array}{l}\text { Mean height } \\
\text { (m) }\end{array}$ & $\begin{array}{c}\text { Mean diameter } \\
(\mathrm{cm})\end{array}$ & $\begin{array}{l}\text { Tree density } \\
\text { (/ha) }\end{array}$ & $\%$ beech & $\begin{array}{c}\text { Basal area } \\
\left(\mathrm{m}^{2}\right)\end{array}$ \\
\hline 8 & Thicket & 2.5 & 1.5 & 16815 & $=80 \%$ & 2.9 \\
\hline 25 & Sapling & 11.2 & 6.2 & 4281 & $>80 \%$ & 15.3 \\
\hline $50 *$ & Pole & 21.8 & 11.0 & 2309 & $>90 \%$ & 22.2 \\
\hline 81 & Young high forest & 27.3 & 29.7 & 304 & $>95 \%$ & 21.1 \\
\hline 145 & Old high forest & 31.6 & 45.4 & 208 & $>95 \%$ & 33.7 \\
\hline
\end{tabular}

* Age and characteristics of this stand in 2000.

in Europe and is widely distributed throughout most of the European countries, as this species has a broad ecological distribution [25]. Natural beech forest covers 19.5 million hectares in Europe [35]. In France, it covers $9 \%$ of the country, i.e. 1.2 million hectares [15], which is an increase of $0.5 \%$ in 10 years [9].

In the literature, most papers report only one stage in stand development, and that is mainly the adult stage. In fact, litter changes quantitatively and qualitatively as the stand ages [19]. The same is true for dead wood returning to the soil, inputs of root organic matter and exported wood. So, it is essential to measure dry matter and carbon stocks throughout the forest rotation to obtain a better idea of what happens to them. This can be done by simulating a forest rotation, using a time sequence consisting of a group of stands of different ages. However, to use this method, site conditions for all the stands must be homogeneous [5, 19, 29, 37].

The carbon stocks in the trees were determined by converting the volume of wood into dry matter, and the result was multiplied by the carbon content. According to the literature, carbon contents vary from 450 to $519 \mathrm{~g} / \mathrm{kg}$. Little information exists about the variability of these contents. There is no indication of a reference value. These approximations may give rise to errors in the determination of accurate carbon stocks in the wood of trees and in comparisons between data [26]. Data showing the variability in carbon levels relative to tree species, tree age and its distribution in the tree are required.

The aim of our work was to: (1) collect data on the quantities of dry matter and carbon biomass immobilised in lowland Atlantic beech forests at the stand scale in a time sequence; (2) evaluate these stocks in the different anatomical, functional or commercial sub-components of the trees; (3) provide data on the carbon levels in beech and the variability relative to the sub-components or age of the trees; (4) determine the quantities of wood exported and the quantities of wood remaining on the ground after thinning and the final felling of the stand. For this, destructive methods were used and statistical regressions were determined.

\section{MATERIALS AND METHODS}

\subsection{Site characteristics}

The site is a 1660 ha beech stand situated in Fougères forest in the north-east of Ille-et-Vilaine (Brittany, France, grid reference: $48^{\circ} 20^{\prime} \mathrm{N}$, $\left.1^{\circ} 10^{\prime} \mathrm{E}\right)$, at an altitude of $115-191 \mathrm{~m}$ above sea level. This forest is dominantly beech (Fagus sylvatica L.) 75\%, with pedunculate oak (Quercus robur L.), sessile oak (Quercus petraea (Mattuschka) Liebl.) $15 \%$, and conifers $8 \%$. The understorey consists essentially of holly (Ilex aquifolium L.). Fougères forest is in the Vaccinio-Quercetum sessiliflora group [4]. The climate in Brittany is oceanic and characterised by an unstable weather system with an abundant, evenly distributed annual precipitation of $900 \mathrm{~mm}$, and a moderate temperature range $\left(12.9^{\circ} \mathrm{C}\right)$. The warmest month (August) has a mean temperature of $17.8^{\circ} \mathrm{C}$ and the minimum temperature of $4.9^{\circ} \mathrm{C}$ is in January. The mean annual temperature is $11^{\circ} \mathrm{C}$ (French Meteorology Data, means of 1951-1980). The soil is an Alocrisol luvisol according to the FAO/ UNESCO soil system with fragic characteristics [13], a weakly leached acid brown soil, which is slightly hydromorphic at depth [33]. The parent material of the forest is derived from the Vire type granite or Brioverian slates at the edge of the forest [33]. The forest is managed as a regular high forest, and it is divided into even-aged stands [1].

Five stands were selected according to the criteria of the time sequence. Their main characteristics are given in Tables I and II. Forest inventories and tree sampling were carried out in 1996 for the 8-yearold thicket stage, the 25-year-old sapling stage and the 81-year-old young high forest stage, in 1999 for the 145-year-old mature high forest stage, and in 2002 for the 50-year-old stand.

\subsection{Method to evaluate dry matter and carbon biomass}

The method used was described by Ranger et al. [28, 29]. The main stages were as follows:

- Forest inventory of an area depending on mean tree size: 16 times $25 \mathrm{~m}^{2}\left(400 \mathrm{~m}^{2}\right)$ in the 10 -year-old thicket stand, 4 times $1040 \mathrm{~m}^{2}\left(4160 \mathrm{~m}^{2}\right)$ in the 27 -year-old sapling stand, 1 time $2425 \mathrm{~m}^{2}$ in the 50-year-old stand, 4 times $1200 \mathrm{~m}^{2}\left(4800 \mathrm{~m}^{2}\right)$ in the 83 -yearold stand and 4 times $1500 \mathrm{~m}^{2}\left(6000 \mathrm{~m}^{2}\right)$ in the 150 -year-old stand.

- Selection of 10 to 16 trees per stand representing all the girth classes derived from the inventory.

- Destructive tree sampling: Each tree was sub-divided into different anatomical or functional components: "non-woody" aerial parts (buds, leaves, flowers, fruits and fruit husks), branches and trunk with diameters inferior to $1 \mathrm{~cm}$ (twigs), branches and trunk with diameter of $1 \mathrm{~cm}$ to $4 \mathrm{~cm}$, trunk wood, trunk bark and roots; and into different commercial components: branches and trunk with diameters between $4 \mathrm{~cm}$ and $7 \mathrm{~cm}$ (firewood), and branches and trunk with diameters between $4 \mathrm{~cm}$ and $7 \mathrm{~cm}$ (industrial wood and timber). Circumference at breast height (C130), total height and fresh biomass by weight were estimated.

The root biomass taken into account was that of all the roots included in the soil around the roots of the stump. The mean area of soil removed (Sre) around the tree was calculated using this equation $\mathrm{Sre}=3 \mathrm{E}-07(\mathrm{C} 130)^{2}+0.0067(\mathrm{C} 130), R^{2}=0.83$. The mean Sre of the stump was $10.2 \mathrm{~m}^{2}$ for the 145 year old stand, $6.5 \mathrm{~m}^{2}$ for the 81 -year-old 
Table II. Main soil characteristics for the site.

\begin{tabular}{lcccccccccccccc}
\hline $\begin{array}{l}\text { Deep } \\
(\mathrm{cm})\end{array}$ & $\mathrm{pH}$ & Density & $\begin{array}{c}\text { Clay } \\
(\mathrm{g} / \mathrm{kg})\end{array}$ & $\begin{array}{c}\text { Silt } \\
(\mathrm{g} / \mathrm{kg})\end{array}$ & $\begin{array}{c}\text { Sand } \\
(\mathrm{g} / \mathrm{kg})\end{array}$ & $\begin{array}{c}\mathrm{C} \text { org. } \\
(\mathrm{g} / \mathrm{kg})\end{array}$ & $\begin{array}{c}\mathrm{N} \text { tot. } \\
(\mathrm{g} / \mathrm{kg})\end{array}$ & $\begin{array}{c}\mathrm{P}_{2} \mathrm{O}_{5} \\
(\mathrm{~g} / \mathrm{kg})\end{array}$ & $\begin{array}{c}\mathrm{Ca} \\
\mathrm{NH}_{4} \mathrm{Cl} \\
(\mathrm{cmol}+\mathrm{kg})\end{array}$ & $\begin{array}{c}\mathrm{Mg} \\
(\mathrm{cmol}+/ \mathrm{kg})\end{array}$ & $\begin{array}{c}\mathrm{K}_{4} \mathrm{Cl} \\
(\mathrm{cmol}+/ \mathrm{kg})\end{array}$ & $\begin{array}{c}\mathrm{Al}^{3} \\
(\mathrm{cmol}+/ \mathrm{kg})\end{array}$ & $\begin{array}{c}\mathrm{BS}_{4} \mathrm{Cl} \\
(\%)\end{array}$ \\
\hline $0-5$ & 3.72 & 0.63 & 181 & 709 & 110 & 75.2 & 4.04 & 0.20 & 0.62 & 0.49 & 0.34 & 4.47 & 20.7 \\
& $(0.07)$ & $(0.04)$ & $(5.7)$ & $(8.4)$ & $(6.2)$ & $(4.3)$ & $(0.32)$ & $(0.01)$ & $(0.15)$ & $(0.07)$ & $(0.03)$ & $(0.22)$ & $(2.6)$ \\
$5-15$ & 4.12 & 1.10 & 156 & 731 & 113 & 26.4 & 1.25 & 0.11 & 0.19 & 0.10 & 0.15 & 4.20 & 9.5 \\
& $(0.05)$ & $(0.05)$ & $(3.1)$ & $(4.1)$ & $(4.3)$ & $(2.1)$ & $(0.10)$ & $(0.01)$ & $(0.04)$ & $(0.01)$ & $(0.02)$ & $(0.20)$ & $(0.8)$ \\
$35-50$ & 4.36 & 1.26 & 128 & 735 & 137 & 6.2 & 0.44 & 0.19 & 0.09 & 0.02 & 0.07 & 1.83 & 10.3 \\
& $(0.05)$ & $(0.03)$ & $(2.0)$ & $(9.0)$ & $(8.9)$ & $(0.7)$ & $(0.03)$ & $(0.04)$ & $(0.02)$ & $(0.002)$ & $(0.005)$ & $(0.12)$ & $(1.1)$ \\
$55-70$ & 4.36 & 1.44 & 160 & 710 & 129 & 2.7 & 0.28 & 0.14 & 0.14 & 0.06 & 0.11 & 3.27 & 11.1 \\
& $(0.05)$ & $(0.02)$ & $(8.2)$ & $(5.4)$ & $(6.3)$ & $(0.4)$ & $(0.02)$ & $(0.02)$ & $(0.06)$ & $(0.005)$ & $(0.006)$ & $(0.33)$ & $(3.4)$ \\
$95-110$ & 4.62 & 1.52 & 219 & 692 & 89 & 1.4 & 0.21 & 0.17 & 0.26 & 0.68 & 0.17 & 5.39 & 17.4 \\
& $(0.06)$ & $(0.02)$ & $(6.4)$ & $(8.4)$ & $(5.1)$ & $(0.1)$ & $(0.01)$ & $(0.02)$ & $(0.06)$ & $(0.19)$ & $(0.007)$ & $(0.22)$ & $(3.4)$ \\
\hline
\end{tabular}

Numbers in brackets correspond to standard error.

stand, $1.3 \mathrm{~m}^{2}$ for the 25 -year-old stand and $0.3 \mathrm{~m}^{2}$ for the young, 8 year-old stand. The roots were dug out for the 25 and 8 -year-old stand. For the 50-year-old stand, no root sampling was carried out. The stumps were transported to the laboratory site where they were washed to remove soil particles.

- Regression models correlating dry weight or carbon biomass with dendrometric parameters (C130) were calculated. The aim was to create a model for each component or sub-component of the trees in each stand.

- Application of the models to the stand inventories to estimate sub-component or total dry matter and carbon biomass, for the above and underground tree components, by stand per hectare. The carbon biomass was also calculated by multiplying the result of the regression models for biomass by the mean concentration of carbon by (sub-)component for the stand.

In addition, the litterfall of each stand was collected and measured every month from the 1st April 1997 to 1st March 1999 [19]. The "nonwoody" aerial parts of the biomass per stand were evaluated in this way.

\subsection{Chemical analyses}

After air drying at $65^{\circ} \mathrm{C}$ to constant weight, and after grinding, the carbon was analysed using the $\mathrm{CHN}$ technique.

\subsection{Statistical analyses}

Statistical analyses were carried out using Unistat 5.0 software. All statistical tests were performed at a 0.05 significance level.

Dry matter and carbon contents of the components or stands, were compared using a one-way ANOVA (variance analysis) with the Tukey-HSD test. When the data distribution was not normal and the variances were not equal, a non-parametric test was used: the KruskalWallis test.

The biomass models were established by using and testing different regression models: linear and non linear. The selection criteria for the best models were as follows: a maximum adjusted $R^{2}$ value, a minimum root mean square error (RMSE) and a good graphic representation of the residues [(calculated value-observed value $)=f$ (calculated value)].

Pearson's correlation coefficient was calculated to test the correlation between wood and bark trunk carbon level.

\section{RESULTS}

\subsection{Biomass immobilisation}

\subsubsection{Dry matter}

It was not possible to use a single model to determine the biomass (dry matter) of each component or sub-component in each stand. The models used were exponential, power, polynomial to the second degree or logarithmic. Examples of these models are given in Table III. These values could only be applied to the $\mathrm{C} 130$ results. In general, the models were good estimates of the dry matter of each component per stand using the dendrometric C130 values: high $R^{2}$ values $\left(R^{2}>0.90\right)$, $p$ values lower than 5 E-04, satisfactory RMSE values and residue graphs. However, the model used for the branches in the young 8-year-old stand gave a lower $R^{2}: 0.88$. In the 25 - and 50 -year-old stands, the models of the biomass of branches with diameters greater than $4 \mathrm{~cm}$ (or the commercial cutting size) gave even lower $R^{2}$ values ( 0.78 and 0.88 respectively) and the highest $p$ values (4.8 E-02 and 1.6 E-03), with an accuracy less than $10 \%$.

An estimate of biomass for each component, in the different age classes, is presented in Table IV. Root biomass was not measured in the 50-year-old stand but estimated using a generalised model for the site. In general, the forest inventories were carried out in several zones, with nearly identical areas for each stand. Within the stand, these zones were used as pseudo-replicates, to provide an estimate of the standard error.

In the 145-year-old stand, total biomass, including all the components, was $496 \mathrm{t} / \mathrm{ha}$. Total biomass was $492 \mathrm{t} / \mathrm{ha}$. The major part of this biomass was contributed by the trunk $(52 \%)$, which itself consisted mainly of the log (90\%) (Fig. 1). The branches represented $37 \%$. The roots made up $11 \%$, i.e. a biomass of $56 \mathrm{t} / \mathrm{ha}$.

Total biomass (aerial and underground; woody and nonwoody) increased with stand age, from 25 t/ha in the young 8 year-old stand to 496 t/ha in the 145-year-old stand (Tab. IV). The contribution of the "non-woody" aerial parts was very low: it decreased with the age of the stand, from $5 \%$ in the young 
Table III. Tested and selected statistical models.

\begin{tabular}{|c|c|c|c|c|c|}
\hline Component & Age (years) & Model & $R^{2}$ & $p$ & C130 interval (mm) \\
\hline \multirow[t]{5}{*}{ Branches } & 8 & $\mathrm{Y}=4.408 \mathrm{E}-06 \times \mathrm{C} 130^{2.5958}$ & 0.88 & $1.0 \mathrm{E}-07$ & $15-148$ \\
\hline & 25 & $\mathrm{Y}=3.787 \mathrm{E}-08 \times \mathrm{C} 130^{3.3843}$ & 0.92 & 4.4 E-09 & $70-875$ \\
\hline & 50 & $\mathrm{Y}=1.495 \mathrm{E}-06 \times \mathrm{C} 130^{2.7063}$ & 0.98 & 7.6 E-11 & $45-1354$ \\
\hline & 81 & $\mathrm{Y}=7.4969 \times \mathrm{e}^{(\mathrm{C} 130 \times 3.047 \mathrm{E}-03)}$ & 0.99 & $1.6 \mathrm{E}-14$ & $270-1687$ \\
\hline & 145 & $\mathrm{Y}=6.05029 \times \mathrm{e}^{(\mathrm{C} 130 \times 3.163 \mathrm{E}-03)}$ & 0.95 & $1.2 \mathrm{E}-06$ & $768-2494$ \\
\hline \multirow[t]{5}{*}{ Trunk } & 8 & $\mathrm{Y}=0.1039 \times \mathrm{e}^{(\mathrm{C} 130 \times 0.02707)}$ & 0.92 & 3.9 E-09 & $15-148$ \\
\hline & 25 & $\mathrm{Y}=2.090 \mathrm{E}-03 \times \mathrm{C} 1301.6427$ & 0.97 & 7.6 E-12 & $70-875$ \\
\hline & 50 & $\mathrm{Y}=7.921 \mathrm{E}-04 \times \mathrm{C} 1301.9002$ & 0.99 & $4.6 \mathrm{E}-11$ & $45-1354$ \\
\hline & 81 & $\mathrm{Y}=\left(5.186 \mathrm{E}-04 \times \mathrm{C} 130^{2}\right)+(0.05066 \times \mathrm{C} 130)-20.3755$ & 0.97 & $8.6 \mathrm{E}-11$ & $270-1687$ \\
\hline & 145 & $\mathrm{Y}=\left(2.77 \mathrm{E}-04 \times \mathrm{C} 130^{2}\right)+(0.8645 \times \mathrm{C} 130)-554.9807$ & 0.95 & $2.8 \mathrm{E}-05$ & $768-2494$ \\
\hline \multirow[t]{5}{*}{ Total aerial wood } & 8 & $\mathrm{Y}=0.1313 \times \mathrm{e}^{(\mathrm{C} 130 \times 0.02830)}$ & 0.94 & $9.1 \mathrm{E}-10$ & $15-148$ \\
\hline & 25 & $\mathrm{Y}=8.551 \mathrm{E}-05 \times \mathrm{C} 130^{2.2603}$ & 0.98 & $6.6 \mathrm{E}-14$ & $70-875$ \\
\hline & 50 & $\mathrm{Y}=2.743 \mathrm{E}-04 \times \mathrm{C} 130^{2.1114}$ & 1.00 & $4.9 \mathrm{E}-13$ & $45-1354$ \\
\hline & 81 & $\mathrm{Y}=69.9608 \times \mathrm{e}^{(\mathrm{C} 130 \times 2.244 \mathrm{E}-03)}$ & 0.98 & $4.6 \mathrm{E}-13$ & $270-1687$ \\
\hline & 145 & $\mathrm{Y}=109.7821 \times \mathrm{e}^{(\mathrm{C} 130 \times 1.953 \mathrm{E}-03)}$ & 0.99 & $1.3 \mathrm{E}-09$ & $768-2494$ \\
\hline \multirow[t]{5}{*}{ Roots } & 8 & $\mathrm{Y}=5.986 \mathrm{E}-05 \times \mathrm{C} 130^{2.02681}$ & 0.93 & $3.3 \mathrm{E}-05$ & $54-205$ \\
\hline & 25 & $\mathrm{Y}=\left(1.303 \mathrm{E}-04 \times \mathrm{C} 130^{2}\right)+(-1.112 \mathrm{E}-02 \times \mathrm{C} 130)+0.2401$ & 0.99 & $2.9 \mathrm{E}-05$ & $43-502$ \\
\hline & 50 & $\mathrm{Y}=2 \mathrm{E}-05 \times \mathrm{C} 130.2 .2396$ & 0.99 & & $200-1400$ \\
\hline & 81 & $\mathrm{Y}=1.641 \mathrm{E}-05 \times \mathrm{C} 130^{2.3141}$ & 0.98 & $1.1 \mathrm{E}-05$ & $500-1400$ \\
\hline & 145 & $\log _{10}(Y)=-4.5221+2.1985 \times \log _{10}(C 130)$ & 0.99 & 4.6 E-04 & $768-2494$ \\
\hline
\end{tabular}

C130: Circumference at breast height in $\mathrm{mm}$; Y: dry matter in $\mathrm{kg}$.

Table IV. Total biomass (dry matter in $\mathrm{kg} / \mathrm{ha}$ ) in the various tree components of the stands.

\begin{tabular}{|c|c|c|c|c|c|c|c|c|c|c|c|}
\hline \multirow{3}{*}{ Component } & & \multicolumn{10}{|c|}{ Age (years) } \\
\hline & & \multicolumn{2}{|c|}{8} & \multicolumn{2}{|c|}{25} & \multicolumn{2}{|c|}{50} & \multicolumn{2}{|c|}{81} & \multicolumn{2}{|c|}{145} \\
\hline & & Mean & $n=16$ & Mean & $n=4$ & Mean & $n=1$ & Mean & $n=4$ & Mean & $n=4$ \\
\hline \multirow[t]{5}{*}{ Branches } & total & 4165 & (790) & 30959 & $(3840)$ & 66562 & & 63537 & $(6430)$ & 188231 & (42 594) \\
\hline & $d<1 \mathrm{~cm}$ & 3417 & $(627)$ & 9031 & $(654)$ & 15171 & & 7759 & $(584)$ & 8041 & (699) \\
\hline & $d>1 \mathrm{~cm}$ & $749 * * *$ & $(170)^{* * *}$ & 22471 & (3 227) & 51453 & & 55751 & $(5824)$ & 181877 & (43 726) \\
\hline & $\mathrm{d}>4 \mathrm{~cm}$ & & & 4621 & (1 137) & 31159 & & 33230 & (4 068) & 160213 & $(46844)$ \\
\hline & $d>7 \mathrm{~cm}$ & & & & & & & 17772 & (2 538) & 139939 & (47 789) \\
\hline \multirow[t]{4}{*}{ Trunk } & total & 13745 & (2 299) & 78970 & (2 277) & 181212 & & 191687 & (12 260) & 261206 & $(18814)$ \\
\hline & $d>4 \mathrm{~cm}$ & & & 72097 & (2 273) & 179821 & & 191209 & (12 273) & 261118 & (18 808) \\
\hline & $d>7 \mathrm{~cm}$ & & & 39377 & (3 402) & 126314 & & 189824 & (12 363) & 260633 & (18 782) \\
\hline & $\log$ & & & & & & & & & 234572 & (16 939) \\
\hline \multicolumn{2}{|c|}{ Total aerial wood } & 18765 & $(3165)$ & 103982 & $(5450)$ & 246096 & & 251116 & $(17678)$ & 436322 & (47 882) \\
\hline \multicolumn{2}{|l|}{ Roots } & 5329 & $(950)$ & 25325 & (1 428) & 41617 & & 50352 & (3 808) & 56035 & (4 342) \\
\hline \multicolumn{2}{|c|}{ Total wood** } & 24094 & (4 107) & 129307 & (6 877) & 287713 & & 301468 & $(21481)$ & 492357 & (51 953) \\
\hline \multicolumn{2}{|c|}{ 'Non-woody' aerial parts* } & 1223 & & 3011 & & & & 3292 & & 3733 & \\
\hline \multicolumn{2}{|l|}{ Total** } & 25317 & & 132318 & & & & 304760 & & 496090 & \\
\hline
\end{tabular}

$n=$ Number of pseudo-replicates; numbers in brackets correspond to standard error; $d=$ diameter.

* Lebret et al. (2001)'s results [7], the number of replicates is different and corresponds to the number of litter traps.

** Results obtained by addition and not by regression.

*** Results obtained by subtraction and not by regression. 
Table V. Mean concentration of carbon in the various tree sub-components according to stand $(\mathrm{g} / \mathrm{kg})$.

\begin{tabular}{|c|c|c|c|c|c|c|c|c|c|c|c|}
\hline \multirow{3}{*}{ Componen } & & \multicolumn{10}{|c|}{ Age (years) } \\
\hline & & \multicolumn{2}{|l|}{8} & \multicolumn{2}{|l|}{25} & \multicolumn{2}{|l|}{50} & \multicolumn{2}{|l|}{81} & \multicolumn{2}{|l|}{145} \\
\hline & & Mean & $n$ & Mean & $n$ & Mean & $n$ & Mean & $n$ & Mean & $n$ \\
\hline \multirow[t]{8}{*}{ Branches } & $d<1 \mathrm{~cm}$ & $475.8 \quad(1.35)$ & 16 & $480.2 \quad(1.00)$ & 16 & 486.9 (1.16) & 10 & $491.7 \quad(2.05)$ & 5 & $484.5 \quad(2.02)$ & 9 \\
\hline & & $\mathrm{a} ; \mathrm{w}$ & & $\mathrm{c} ; \mathrm{w}-\mathrm{x}$ & & $\mathrm{b} ; \mathrm{y}-\mathrm{z}$ & & $\mathrm{b} ; \mathrm{z}$ & \multicolumn{3}{|c|}{$\mathrm{b} ; \mathrm{x}-\mathrm{y}$} \\
\hline & $1 \mathrm{~cm}<d<4 \mathrm{~cm}$ & $472.7 \quad(1.27)$ & 8 & $462.6 \quad(1.06)$ & 16 & $481.3 \quad(0.87)$ & 11 & 477.8 (1.96) & 5 & $472.0 \quad(1.80)$ & 10 \\
\hline & & $a ; x-y$ & & $\mathrm{a} ; \mathrm{w}$ & & $\mathrm{a} ; \mathrm{z}$ & & $a ; y-z$ & \multicolumn{3}{|c|}{$\mathrm{a} ; \mathrm{x}$} \\
\hline & \multirow[t]{2}{*}{$4 \mathrm{~cm}<d<7 \mathrm{~cm}$} & & & $470.3 \quad(1.42)$ & 7 & $480.2 \quad(1.30)$ & 7 & $477.5 \quad(2.30)$ & 4 & $473.4 \quad(1.38)$ & 10 \\
\hline & & & & $\mathrm{b} ; \mathrm{x}$ & & $\mathrm{a} ; \mathrm{z}$ & & $a ; y-z$ & \multicolumn{3}{|c|}{$a ; x-y$} \\
\hline & \multirow[t]{2}{*}{$d>7 \mathrm{~cm}$} & & & $463.1 \quad(4.41)$ & 4 & $481.5 \quad(1.04)$ & 4 & $475.4 \quad(2.68)$ & 3 & $469.1 \quad(1.92)$ & 8 \\
\hline & & & & $\mathrm{a} ; \mathrm{x}$ & & $\mathrm{a} ; \mathrm{z}$ & & $a ; y-z$ & & a; x-y & \\
\hline \multirow[t]{14}{*}{ Trunk } & $d<1 \mathrm{~cm}$ & $481.0 \quad(0.92)$ & 16 & $483.1 \quad(1.93)$ & 16 & $487.7 \quad(0.88)$ & 13 & $485.7 \quad(2.21)$ & 3 & 488.1 & 10 \\
\hline & & $\mathrm{x}$ & & $x-y$ & & \multirow[t]{2}{*}{$\mathrm{y}$} & & $x-y$ & \multicolumn{3}{|c|}{$\mathrm{y}$} \\
\hline & $1 \mathrm{~cm}<d<4 \mathrm{~cm}$ & $487.2 \quad(1.24)$ & 16 & $503.0 \quad(3.45)$ & 16 & & & $492.9(1.15)$ & 4 & $496.5 \quad(2.23)$ & 10 \\
\hline & & $\mathrm{x}$ & & $\mathrm{b} ; \mathrm{y}$ & & & & $b ; x-y$ & & $b ; x-y$ & \\
\hline & $4 \mathrm{~cm}<d<7 \mathrm{~cm}$ & & & $494.2 \quad(1.85)$ & 16 & $497.5 \quad(1.29)$ & 6 & 487.1 & 5 & $490.1 \quad(2.18)$ & 10 \\
\hline & & & & $a-b ; x-y$ & & $\mathrm{a} ; \mathrm{y}$ & & $a ; x$ & & $a-b ; x-y$ & \\
\hline & $d>7 \mathrm{~cm}$ & & & $486.4 \quad(3.43)$ & 13 & $495.6 \quad(1.66)$ & 10 & 486.8 & 5 & $485.7 \quad(2.29)$ & 10 \\
\hline & & & & $\mathrm{a} ; \mathrm{x}$ & & $\mathrm{a} ; \mathrm{x}$ & & $\mathrm{a} ; \mathrm{x}$ & & $\mathrm{a} ; \mathrm{x}$ & \\
\hline & $1 \mathrm{~cm}<d<4 \mathrm{~cm}$ & $466.5 \quad(0.61)$ & 16 & $469.5 \quad(2.19)$ & 16 & & & $473.8 \quad(7.17)$ & 5 & $464.9 \quad(0.86)$ & 10 \\
\hline & & $\mathrm{x}$ & & $\mathrm{a} ; \mathrm{x}$ & & & & $\mathrm{a} ; \mathrm{x}$ & & $\mathrm{a} ; \mathrm{x}$ & \\
\hline & $4 \mathrm{~cm}<d<7 \mathrm{~cm}$ & & & $471.7 \quad(1.82)$ & 16 & $476.5 \quad(0.83)$ & 6 & $482.6 \quad(2.39)$ & 5 & $467.9 \quad(1.69)$ & 10 \\
\hline & & & & $a ; x-y$ & & $a ; y-z$ & & $\mathrm{a} ; \mathrm{z}$ & & $\mathrm{a} ; \mathrm{x}$ & \\
\hline & $\mathrm{d}>7 \mathrm{~cm}$ & & & $474.4 \quad(2.82)$ & 13 & $476.8 \quad(0.29)$ & 10 & $481.4 \quad(2.47)$ & 5 & $469.2 \quad(2.20)$ & 10 \\
\hline & & & & $a ; x-y$ & & $a ; x-y$ & & $\mathrm{a} ; \mathrm{y}$ & & $\mathrm{a} ; \mathrm{x}$ & \\
\hline Roots & & $479.4 \quad(1.83)$ & 9 & $489.4 \quad(2.39)$ & 6 & & & $484.3 \quad(1.02)$ & 7 & $489.4 \quad(1.64)$ & 5 \\
\hline & & $\mathrm{x}$ & & $\mathrm{y}$ & & & & $x-y$ & & $\mathrm{y}$ & \\
\hline
\end{tabular}

$n=$ Number of pseudo-replicates; numbers in brackets correspond to standard error; $d=$ diameter.

$\mathrm{a}, \mathrm{b}, \mathrm{c}$ : By stand, different letters indicate a significant difference $(p<0.05)$ between sub-components.

$\mathrm{w}, \mathrm{x}, \mathrm{y}, \mathrm{z}$ : By sub-component, different letters indicate a significant difference $(p<0.05)$ between stands

8 -year-old stand to less than $1 \%$ in the oldest stand. In the time sequence, total biomass increased from $24 \mathrm{t} / \mathrm{ha}$ to $492 \mathrm{t} / \mathrm{ha}$. This increase in stock was not linear. It showed a plateau between the 50- and the 81-year-old stages. The biomass is mainly stored in the trunk, then the branches and then the roots (Fig. 1). Throughout the time sequence, the contributions by the trunk, branches and roots, fluctuated between $52 \%$ and $63 \%, 18 \%$ to $37 \%$, and $11 \%$ to $23 \%$ respectively. The distribution of the aerial biomass (trunk and branches) moved towards thicker wood (diameters greater than $4 \mathrm{~cm}$ ) to the detriment of thinner twigs (diameters less than $4 \mathrm{~cm}$ ): $6 \%$ for the latter in the 145-yearold stage.

\subsubsection{Carbon biomass}

\subsubsection{Levels}

The mean carbon levels in the components sampled from each stand are given in Table V. The carbon concentrations var- ied from $462.6 \mathrm{~g} / \mathrm{kg} \pm 1.1$ to $503.0 \mathrm{~g} / \mathrm{kg} \pm 3.5$. For wood in the trunk, the values did not vary significantly between different sampling heights, whatever the stand. This was not true for the branch and bark sub-components. Levels in most of the subcomponents varied significantly with the age of the stand, except for the bark of industrial trunks greater than $7 \mathrm{~cm}$ and industrial trunk wood 1 to $4 \mathrm{~cm}$ in diameter.

For each tree, in each stand, the carbon contents of the branches were calculated from the carbon levels in the subcomponents of the branch in proportion to the dry weight. The same principle was applied to the calculation of carbon levels in the trunk bark, trunk wood, trunk (wood + bark) and the aerial parts. These weighted mean values are given in Table VI. In all stands, the carbon levels were significantly higher in the bark than in the trunk wood $(p<0.00001)$. These levels had very low correlations $\left(r_{\max }=-0.50 ; r_{\min }=-0.03\right)$. By stand, carbon contents in the aerial part, the trunk, the branches and the roots are not significantly different in the 81-year-old stand. By components, 


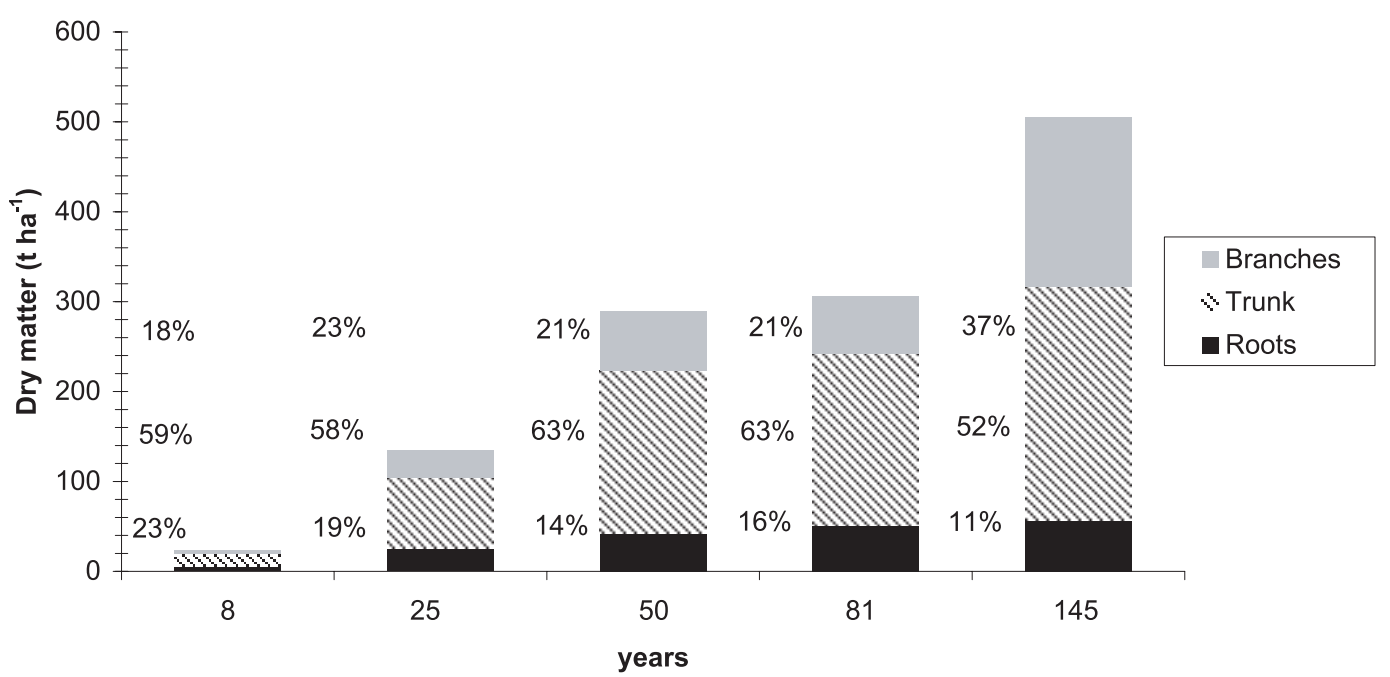

Figure 1. Woody dry matter distribution (in t/ha and \%) in beech trees, for each stand. The carbon biomass distribution in $\%$ was similar.

Table VI. Mean concentration of carbon in the tree components according to stand $(\mathrm{g} / \mathrm{kg})$.

\begin{tabular}{|c|c|c|c|c|c|c|c|c|c|c|}
\hline \multirow{3}{*}{ Component } & \multicolumn{10}{|c|}{ Age (years) } \\
\hline & \multicolumn{2}{|l|}{8} & \multicolumn{2}{|l|}{25} & \multicolumn{2}{|l|}{50} & \multicolumn{2}{|l|}{81} & \multicolumn{2}{|l|}{145} \\
\hline & Mean & \multirow{2}{*}{$\frac{n}{16}$} & Mean & \multirow{2}{*}{$\frac{n}{16}$} & Mean & \multirow{2}{*}{$\frac{n}{10}$} & Mean & \multirow{2}{*}{$\frac{n}{5}$} & Mean & \multirow{2}{*}{$\frac{n}{7}$} \\
\hline Branches & $475.5 \quad(1.28)$ & & $469.9 \quad(1.23)$ & & $484.0 \quad(1.12)$ & & $480.5 \quad(2.19)$ & & $471.0 \quad(1.73)$ & \\
\hline & b-c; $x-y$ & & $\mathrm{a} ; \mathrm{x}$ & & $\mathrm{b} ; \mathrm{z}$ & & $a ; y-z$ & & $\mathrm{a} ; \mathrm{x}$ & \\
\hline \multirow[t]{6}{*}{ Trunk } & $470.4 \quad(0.51)$ & 16 & $474.4 \quad(1.90)$ & 16 & $478.6 \quad(0.36)$ & 13 & $478.9 \quad(4.81)$ & 2 & $470.5 \quad(2.62)$ & 10 \\
\hline & $a ; x$ & & $\mathrm{a} ; \mathrm{x}$ & & $\mathrm{a} ; \mathrm{x}$ & & $\mathrm{a} ; \mathrm{x}$ & & $a ; x$ & \\
\hline & $487.2 \quad(1.25)$ & 16 & $491.4 \quad(2.74)$ & 16 & $496.0 \quad(1.42)$ & 12 & $486.4 \quad(1.62)$ & 4 & $485.7 \quad(2.27)$ & 10 \\
\hline & $x-y$ & & $x-y$ & & $\mathrm{y}$ & & $x-y$ & & $\mathrm{x}$ & \\
\hline & $466.5 \quad(0.61)$ & 16 & $473.0 \quad(2.21)$ & 16 & $476.4 \quad(0.36)$ & 12 & $481.5 \quad(2.45)$ & 5 & $469.2 \quad(2.20)$ & 10 \\
\hline & $\mathrm{x}$ & & $x-y$ & & $\mathrm{y}$ & & $\mathrm{y}$ & & $x-y$ & \\
\hline \multirow[t]{2}{*}{ Total aerial wood } & $471.5 \quad(0.42)$ & 16 & $472.1 \quad(1.09)$ & 16 & $479.6 \quad(0.28)$ & 10 & $477.5 \quad(3.08)$ & 2 & $468.8 \quad(1.67)$ & 7 \\
\hline & $a-b ; x$ & & $\mathrm{a} ; \mathrm{x}$ & & $\mathrm{a} ; \mathrm{y}$ & & $a ; x-y$ & & $\mathrm{a} ; \mathrm{x}$ & \\
\hline Roots & $479.4 \quad(1.83)$ & 9 & $489.4 \quad(2.39)$ & 6 & nd & & $484.3 \quad(1.02)$ & 7 & $489.4 \quad(1.64)$ & 5 \\
\hline
\end{tabular}

$n=$ Number of samples; numbers in brackets correspond to standard error; nd: non-determined data.

a, b: By stand, different letters indicate a significant difference $(p<0.05)$ between components.

$\mathrm{x}, \mathrm{y}$ : By component, different letters indicate a significant difference $(p<0.05)$ between stands. 81-year old-stand was not taken into account because of the low number of samples.

carbon contents varied significantly depending on stand age, except for the trunk.

\subsubsection{Carbon biomass}

Two methods were used to determine the carbon biomass in each component of each stand. The first was: by stand, component and individual, the carbon biomass was obtained by multiplying the quantity of dry matter by the carbon level. The second method was: by stand, component and individual, the carbon biomass was obtained by regression from the $\mathrm{C} 130 \mathrm{fac}-$ tor. In a complementary trial comparison, the same carbon value was chosen and applied to each stand, component and individual: either the lowest estimated carbon level (463 g/ $\mathrm{kg}$ ), or the highest $(503 \mathrm{~g} / \mathrm{kg})$. The carbon biomass values per hectare obtained were then compared. A few comparisons are given in Figure 2. For each stand and each component, the carbon biomass per hectare obtained by the different methods showed no significant differences.

In the following text, the carbon biomass values are those derived from the first method (Tab. VII). Carbon biomass stored in the aerial and underground parts changed throughout 
Table VII. Carbon biomass (dry matter in $\mathrm{kg} / \mathrm{ha}$ ) in the various tree sub-components of the stands according to method 1.

\begin{tabular}{|c|c|c|c|c|c|c|c|c|c|c|c|}
\hline \multirow{3}{*}{ Component } & & \multicolumn{10}{|c|}{ Age (years) } \\
\hline & & \multicolumn{2}{|c|}{8} & \multicolumn{2}{|c|}{25} & \multicolumn{2}{|c|}{50} & \multicolumn{2}{|c|}{81} & \multicolumn{2}{|c|}{145} \\
\hline & & Mean & $n=16$ & Mean & $n=4$ & Mean & $n=1$ & Mean & $n=4$ & Mean & $n=4$ \\
\hline \multirow[t]{5}{*}{ Branches } & total & 1981 & (376) & 14547 & (1 804) & 32213 & & 30527 & (3 090) & 88654 & $\left(\begin{array}{ll}20 & 061)\end{array}\right.$ \\
\hline & $d<1 \mathrm{~cm}$ & 1626 & (298) & 4336 & $(314)$ & 7387 & & 3815 & (287) & 3896 & $(338)$ \\
\hline & $d>1 \mathrm{~cm}$ & $355^{*}$ & $(180)^{*}$ & 10408 & (1 495) & 24771 & & 26650 & (2 784) & 85525 & (20 561) \\
\hline & $d>4 \mathrm{~cm}$ & & & & & 17257 & & 15834 & (1938) & 75257 & (22 004) \\
\hline & $d>7 \mathrm{~cm}$ & & & & & & & 8450 & (1 206) & 65643 & (22 417) \\
\hline \multirow[t]{4}{*}{ Trunk } & total & 6465 & $\left(\begin{array}{ll}1 & 081\end{array}\right)$ & 37467 & $\left(\begin{array}{ll}1 & 080)\end{array}\right.$ & 86722 & & 92139 & (5 914) & 122895 & (8 852) \\
\hline & $d>4 \mathrm{~cm}$ & & & 34207 & $\left(\begin{array}{ll}1 & 078\end{array}\right)$ & 86027 & & 91794 & (5 871) & 122853 & (8 849) \\
\hline & $d>7 \mathrm{~cm}$ & & & 18712 & (1 617) & 60364 & & 91457 & (5 956) & 122625 & (8 837) \\
\hline & $\log$ & & & & & & & & & 110364 & (7 970) \\
\hline \multicolumn{2}{|c|}{ Total aerial wood } & 8847 & (1 492) & 49087 & (2 573) & 118018 & & 119920 & (8 442) & 204552 & (22 448) \\
\hline \multicolumn{2}{|l|}{ Roots } & 2555 & $(455)$ & 12393 & (699) & 20261 & & 24385 & (1 844) & 27425 & $(2125)$ \\
\hline \multicolumn{2}{|c|}{ Total wood** } & 11402 & (1 999) & 61480 & (3 271) & 138279 & & 144305 & (10 284) & 231977 & (24 441) \\
\hline
\end{tabular}

$n=$ Number of pseudo-replicates; numbers in brackets correspond to standard error; $d=$ diameter.

* Results obtained by subtraction.

** Results obtained by addition of roots to total aerial carbon biomass.

the time sequence from $11 \mathrm{t} / \mathrm{ha}$ in the young $(8 \mathrm{yrs})$ stand to $232 \mathrm{t} / \mathrm{ha}$ in the old (145 yrs) stand. The distribution of carbon biomass in the woody components was very similar to that of the total biomass of the same components (Fig. 1). This was due to the carbon concentrations in the different woody components of the tree which were about $500 \mathrm{~g} / \mathrm{kg}$ of dry matter.

\subsection{Exported biomass}

Even though it was not possible to generalise from these biomass estimation models, it was possible to create a scenario of the evolution of stocks and exports during a forest rotation.

The number of individuals per hectare decreased by $82.6 \%$ between the 8-year-old and the 25-year-old stands, by $57.5 \%$ between the 25 - and the 50 -old-year old stands, by $81.7 \%$ between those of 50- and 81-years-old, by $49.2 \%$ between those of 81 - and 145 -years-old and $100 \%$ between 145-years-old stand and the stand at the end of regeneration. These percentages were used to make a rough approximation of biomass exports between the consecutive stages studied. The growth models developed elsewhere will be added in the future to refine export evaluations.

During thinning, not all the wood was removed, so part was left on the ground. The components of the tree which were most likely to be exported were: the parts of branches and trunk with a diameter between 4 and $7 \mathrm{~cm}$, and those with a diameter greater than $7 \mathrm{~cm}$. Woody material remaining on the ground consisted of twigs, pieces of branch with diameters between 1 and $4 \mathrm{~cm}$, and pieces of trunk less than $4 \mathrm{~cm}$. The roots of felled trees remained in the soil. The beech wood was not debarked. During thinning between the 8- and 25-year-old stages, all the brashed wood was left on the ground, and was thus returned into the ecosystem.

\subsubsection{Dry matter}

In the time sequence, total aerial biomass exported was estimated to be $749 \mathrm{t} / \mathrm{ha}$, that left on the ground to be $107 \mathrm{t} / \mathrm{ha}$, and the total biomass of the remaining roots of the felled trees left in the soil was $134 \mathrm{t} / \mathrm{ha}$. Throughout the whole forest rotation, the percentage of wood exported, relative to the biomass immobilised before thinning, increased from 0 to $83 \%$; that of wood left on the ground decreased from $64 \%$ to $5 \%$; and that of remaining roots left in the soil changed from 8 to $18 \%$ (Fig. 3). During the rotation, wood exported came mainly from the tree trunks (Fig. 4). During regeneration felling, the wood had two main origins: the trunk $(62 \%)$ and the $7 \mathrm{~cm}$ industrial branch $\operatorname{wood}(33 \%)$.

\subsubsection{Carbon biomass}

Total carbon biomass in the aerial wood exported, during the rotation, was estimated to be $355 \mathrm{t} / \mathrm{ha}$, that of aerial wood left on the ground: $52 \mathrm{t} / \mathrm{ha}$, and that of the remaining roots left in the soil: $65 \mathrm{t} / \mathrm{ha}$. The future or the percentage distribution, of the carbon biomass, after each thinning, was similar to that of the total biomass (Figs. 3 and 4).

\section{DISCUSSION}

\subsection{The models}

This paper presents regression models to evaluate the total biomass in tree in several different age beech stands, using one simple measurement (C130). One particular characteristic of the work is the determination of regression models to evaluate 
Woody aerial part

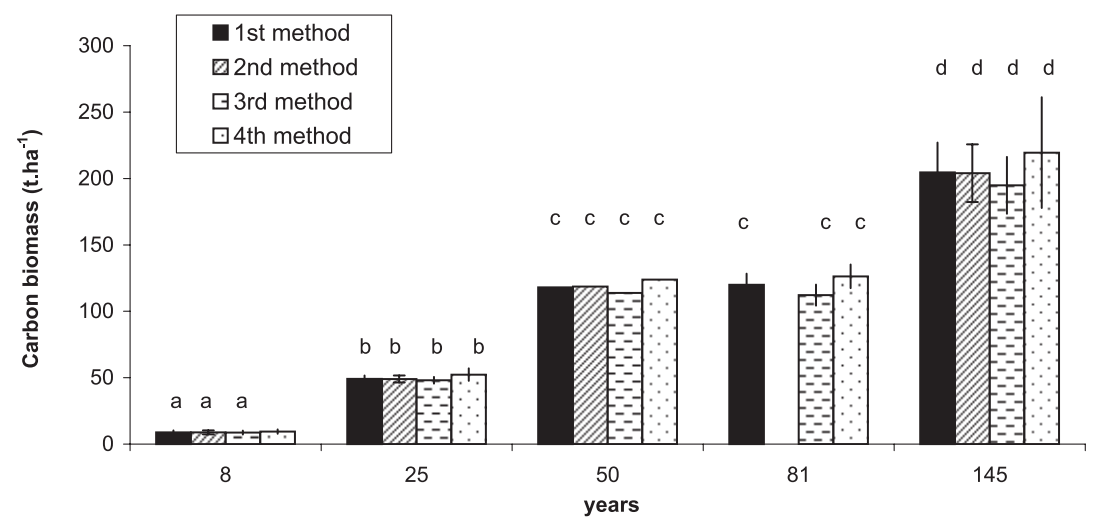

Branches

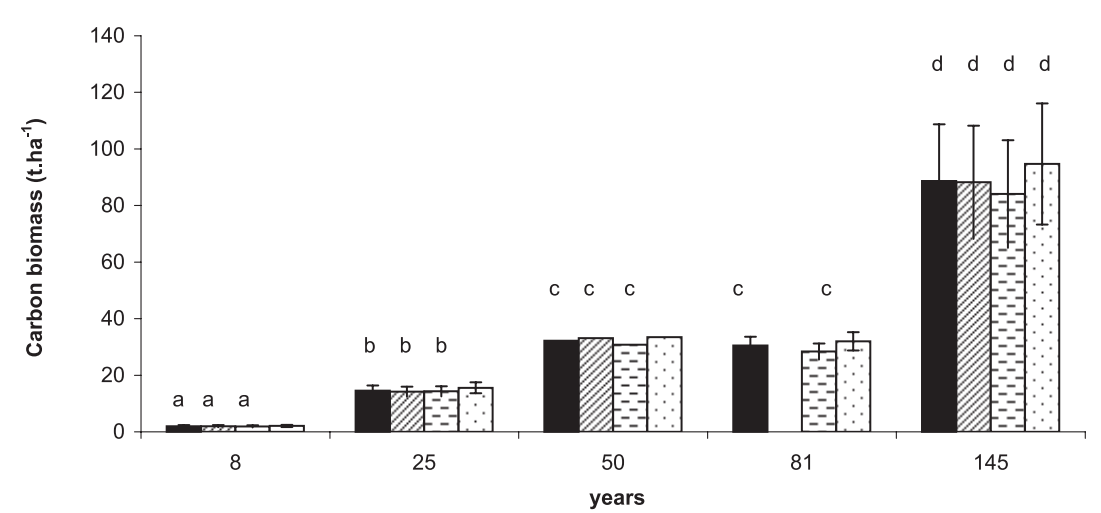

Trunk

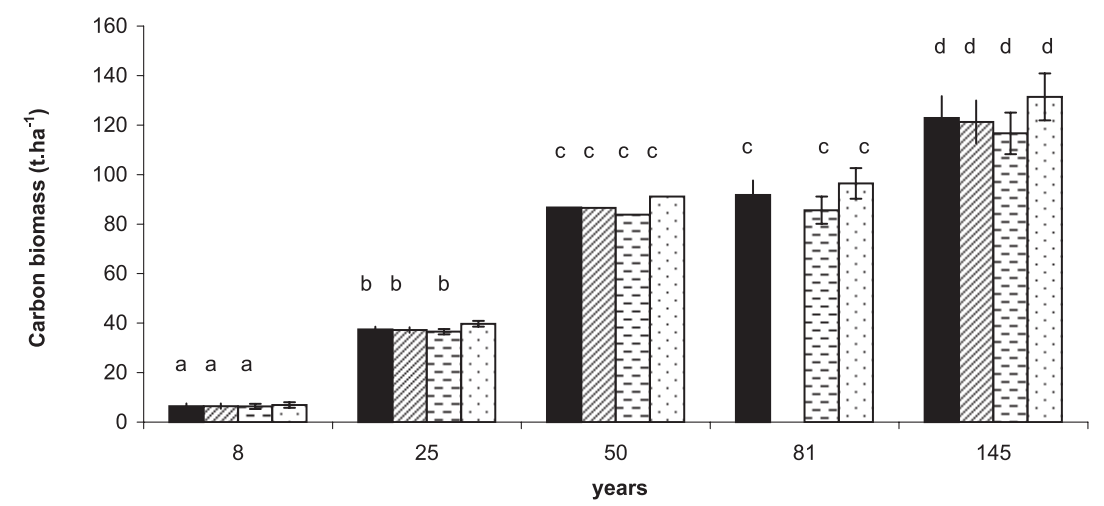

Root

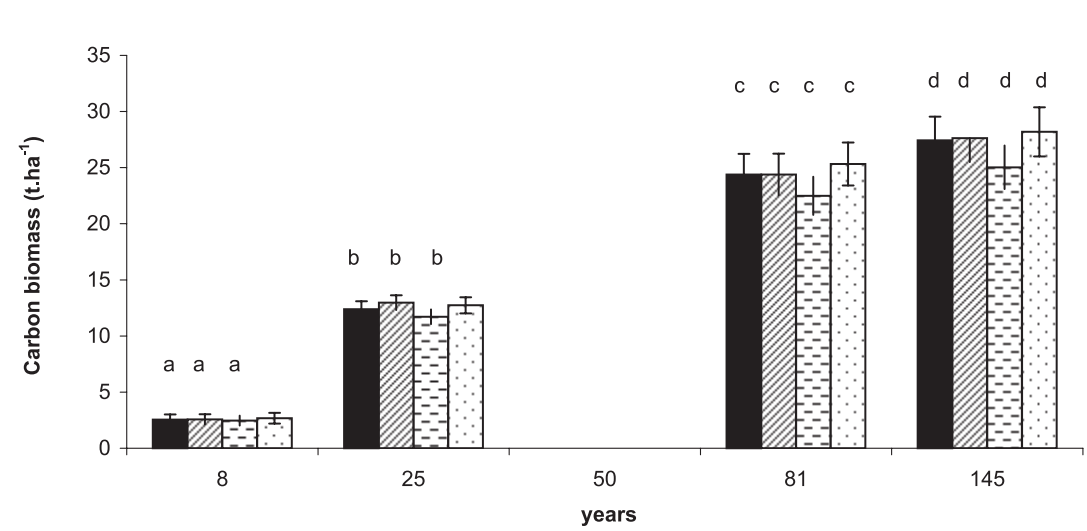

Figure 2. Comparison of the carbon biomass of the main tree components $(\mathrm{t} / \mathrm{ha})$ obtained by different methods, for each stand. Method 1 : by individual, carbon biomass $=$ dry matter $\times$ carbon concentration; Method 2: by individual, carbon biomass is obtained by one parameter regression (C130); Method 3: by individual, carbon biomass $=$ dry matter $\times 462.6 \mathrm{~g} / \mathrm{kg}$ whatever the sub-component and the stand; Method 4: by individual, carbon biomass $=$ dry matter $\times 503.0 \mathrm{~g} / \mathrm{kg}$ whatever the sub-component and the stand. a, b, c, d: by component, different letters indicate significantly different biomasses $(p<0.01)$. 


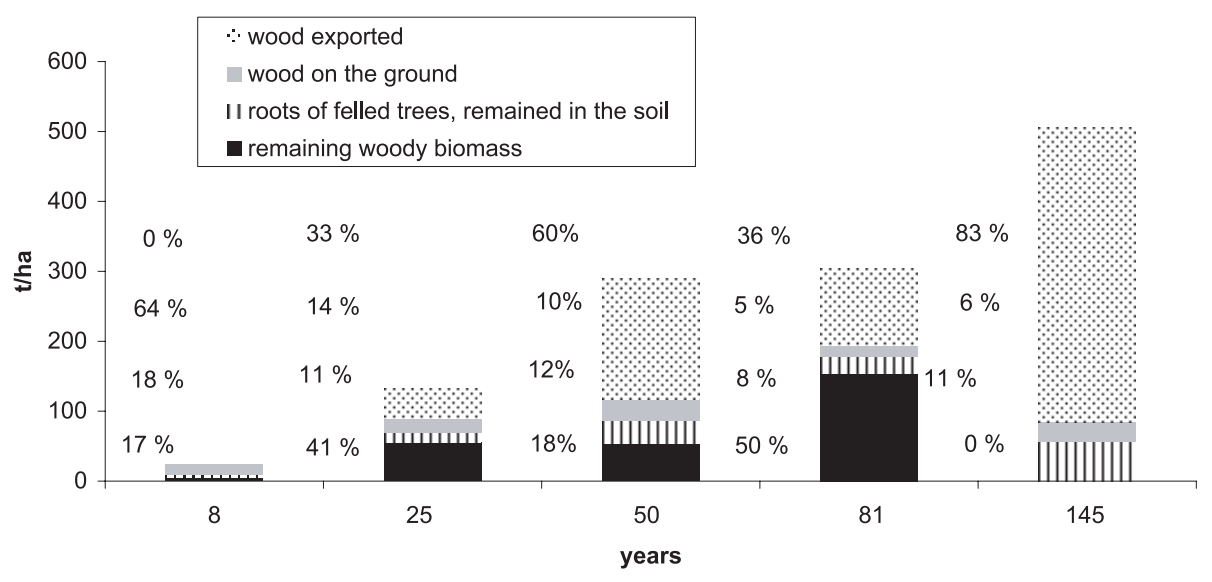

Figure 3. Dry matter distribution after exploitation (in $\mathrm{t} / \mathrm{ha}$ and $\%$ ). The carbon biomass distribution in $\%$ was similar.

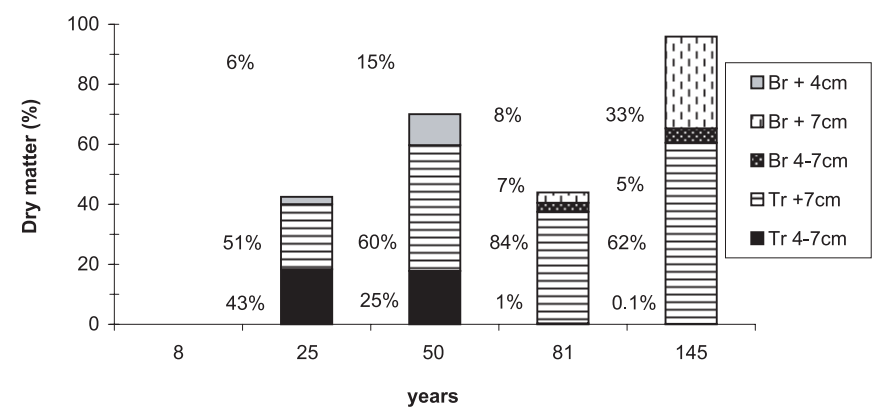

Figure 4. Exported dry matter distribution: (1) relative to initial biomass (\%); (2) relative to exported biomass (\%). The distributions were similar for the carbon biomass.

the biomass of the different components and sub-components of the beech tree.

At present, there is considerable interest in estimates of forest biomass, in relation to practical and forest management questions, but also in scientific domains. Forest biomass estimates provide data which can be used to calculate carbon fluxes in forest ecosystems [18], in sustainable forestry [31], and to simulate forest production and nutrient cycling [16]. However, Koerper and Richardson [17] showed that there could be considerable errors in biomass estimates if regression equations of biomass established in one area were used in other areas. Wang et al. [36] showed that errors in biomass estimates using tariffs could result from: (1) the use of an equation developed in a completely different region without checking its validity in that area; (2) the use of an equation outside the $\mathrm{C} 130$ range; (3) the use of equations within their $\mathrm{C} 130$ range but without respecting the density, age, site characteristics and plot development conditions. This background data for our work is given in Tables I, II and III, and in the section describing the materials and methods.

\subsection{Beech dry matter}

In Table VIII, data on beech biomass found in the literature are presented. In fact, there were few references, they were not recent and the estimates were very variable. The old, 145-yearold, high forest beech stand in Fougères forest had an aerial biomass (woody and non-woody) (440 t/ha) which was higher than those give in the literature. This was not the case for the root biomass ( $56 \mathrm{t} / \mathrm{ha})$. It is difficult to compare biomass stocks. In fact, beech, like other species, varies from one forest to another, depending on the climate, soil, age, density and management of the stands [10,21]. Dagnelie [6] cited the ecological factors to which site quality was linked significantly: geographical location, site aspect, altitude, soil profile evolution and drainage and humus conditions. Site history may also play a significant role. In addition, the methods used to evaluate biomass are not always comparable. This may also contribute to the differences in biomass evaluation, especially that of the branches. Nabuurs et al. [26], in a study of the role of European forests in global carbon cycling, grouped European forest carbon balance studies together. They noted, that even if these inventories were relatively simple it was difficult to compare the results, and some differences in results were inexplicable due to a combination of small differences in the methods.

It is worth noting that the root dry matter values were underestimated is this present study because of the methodology. Part of the fine roots (diameter $<2 \mathrm{~mm}$ ) were probably lost in the cleaning process. The coarse roots biomass (diameter $>2 \mathrm{~mm}$ ) may have been under-estimated because broken coarse roots at the stump periphery were not all taken in spite of the careful sampling. A complementary study is underway to estimate the fine root biomass, but the percentage of very fine roots is less than $2 \%$ of the total root biomass.

\subsection{Carbon levels}

Carbon stock estimates in the plant components require both information on dry matter and the concentration of carbon in the various tissues. Certain authors commonly used a pre-established carbon value of $500 \mathrm{~g} / \mathrm{kg}$ [34]. Other authors considered that the use of such value could introduce very large over- or under-estimates of carbon biomass into the calculation [14].

In this study, carbon contents in the trunk component varied depending on the position of the sample along the trunk. The 
Table VIII. Dry matter data from several stands of beeches in Europe (ordered by age).

\begin{tabular}{|c|c|c|c|c|c|c|c|c|c|c|c|}
\hline \multirow[t]{2}{*}{ Country } & \multirow[t]{2}{*}{$\begin{array}{l}\text { Altitude } \\
\text { (m) }\end{array}$} & \multirow[t]{2}{*}{$\begin{array}{l}\text { Age } \\
\text { (year) }\end{array}$} & \multirow[t]{2}{*}{$\begin{array}{l}\text { Tree density } \\
\text { (/ha) }\end{array}$} & \multirow[t]{2}{*}{$\begin{array}{c}\text { Basal area } \\
\left(\mathrm{m}^{2} / \mathrm{ha}\right)\end{array}$} & \multicolumn{6}{|c|}{$\begin{array}{l}\text { Dry matter } \\
\text { (t/ha) }\end{array}$} & \multirow[t]{2}{*}{ References } \\
\hline & & & & & Stem & Branches & Fruits & Leaves & Total aerial & Roots & \\
\hline West France & $115-191$ & 10 & 16815 & 3 & 14 & 4 & 0 & 1.2 & $20^{*}$ & 5 & Huet et al., in this paper \\
\hline West France & $115-191$ & 27 & 4281 & 15 & 79 & 31 & 0 & 2.8 & $107 *$ & 25 & Huet et al., in this paper \\
\hline France, Fontainebleau & 135 & 25-30 & 5000 & 18 & \multicolumn{2}{|c|}{$(71)$} & 0 & 3.8 & 75 & 14 & Lemée, 1978 [21] \\
\hline North-East France & 300 & 30 & 3500 & 16 & 65 & 11 & & 2.4 & 78 & 15 & Granier et al., 2000 [12] \\
\hline North-East France & 300 & 30 & 3500 & 16 & & & & & & 16 & Le Goff and Ottorini \\
\hline Denmark & 200 & 47 & 1433 & 19 & 129 & & & 2.1 & & & Möller 1945, 1954 *** \\
\hline West France & $115-191$ & 50 & & & 181 & 67 & 0 & & & & Huet et al., in this paper \\
\hline Denmark & 200 & 54 & 956 & 21 & 153 & & & 2.2 & & & Möller 1945, 1954 *** \\
\hline Denmark & 200 & 58 & 1266 & 18 & 124 & & & 2.5 & & & Möller 1945, 1954 *** \\
\hline Germany & $430-500$ & 59 & 3620 & 30 & 110 & 42 & 0.3 & 3.2 & 156 & 24 & Ellenberg, 1971, 1981*** \\
\hline Germany & $430-500$ & 80 & 1190 & 25 & 130 & 26 & 0.3 & 3.3 & 160 & 22 & Ellenberg, 1971, 1981*** \\
\hline West France & $115-191$ & 83 & 304 & 21 & 192 & 64 & 0.1 & 2.8 & $254^{*}$ & 50 & Huet et al., in this paper \\
\hline Denmark & 30 & 90 & 370 & 29 & 170 & 43 & & 2.1 & 215 & 43 & Holm and Jensen, 1981** \\
\hline Bulgarie & 1500 & 100 & 2000 & 42 & 280 & 32 & & 2.9 & 315 & 38 & Garelkov, $1973 * *$ \\
\hline Bulgarie & 1500 & 100 & 1200 & 48 & 365 & 49 & & 4.7 & 419 & 50 & Garelkov, $1973 * *$ \\
\hline Germany & 300 & 116 & 262 & 33 & 349 & 38 & 2.5 & 3.2 & 393 & & Pellinen, $1986 * *$ \\
\hline Denmark & 200 & 118 & 271 & 30 & 322 & & & 2.6 & & & Möller 1945, 1954 *** \\
\hline Belgium & 595 & 120 & 199 & 25 & 151 & 114 & 0.04 & 3.5 & 269 & 62 & Devillez et al., 1973 [10] \\
\hline Germany & $430-500$ & 122 & 243 & 28 & 238 & 33 & 0.4 & 3.1 & 275 & 30 & Ellenberg, 1971, 1981*** \\
\hline Belgium, Mirwart nue & 350 & 130 & 190 & 29 & 169 & 109 & 0.5 & 2.9 & 281 & 68 & Duvigneaud, 1977 [11] \\
\hline Belgium, Mirwart & 350 & 144 & 156 & 31 & 225 & 144 & 1.3 & 2.8 & 373 & 74 & Duvigneaud, 1977 [11] \\
\hline West France & $115-191$ & 147 & 208 & 34 & 261 & 188 & 0.2 & 3.1 & $440^{*}$ & 56 & Huet et al., in this paper \\
\hline Denmark & 200 & 150 & 300 & 30 & 284 & & & 2.9 & & & Möller 1945, 1954 *** \\
\hline France, Fontainebleau & 135 & 150 & 350 & $30-35$ & 232 & 58 & 1.2 & 3.5 & 246 & 49 & Lemée, 1978 [21] \\
\hline Denmark & 200 & 200 & 154 & 28 & 311 & & & 2.6 & & & Möller 1945, 1954 *** \\
\hline
\end{tabular}

* Results obtained by addition of total aerial wood biomass obtained by regression and non-woody aerial part biomass (cf. Tab. IV); ** in Cannell, 1982 [2]; *** in Röhrig, 1991 [30].

same was true for carbon contents in the branches. Consequently, evaluations of carbon contents in these two components should be made using samples from several slices, with different diameters. Conversely, when the concentrations in the trunk and/or branch and/or roots components were not significantly different, determination of carbon contents could be limited to a single sample of trunk or branches. In all cases, it was essential to sample each stand. Millier et al. [24] found similar results relating to the necessity of sampling sub-components for mineralomass studies. However, tests showed that such detailed analysis was not as essential for carbon biomass estimations of the components at the stand scale. A pre-established carbon value of $500 \mathrm{~g} / \mathrm{kg}$ ( $475 \mathrm{~g} / \mathrm{kg}$ for beech stands, this case study) can be used without introducing a large margin of error. This was mainly explained by the existence of a spatial variation of the biomass (dry matter) distribution of trees at the outset, and the low statistical weight of the carbon content in the equation to calculate carbon biomass.

\subsection{Carbon biomass}

Carbon stocks in the aerial parts of beech changed during the rotation, from $9 \mathrm{t} / \mathrm{ha}$ in the young ( $8 \mathrm{yrs}$ ) stand to $205 \mathrm{t} / \mathrm{ha}$ in the old (145 yrs) stand, and those in the roots from $3 \mathrm{t} / \mathrm{ha}$ to $27 \mathrm{t} / \mathrm{ha}$. As for the biomass, it was difficult to compare these stock values with those of other forest ecosystems. The influence of various parameters explained these differences.

Due to the carbon levels which were very close to $500 \mathrm{~g} / \mathrm{kg}$, the carbon biomass of the different (sub-)components was nearly always equal to half of the total biomass of the corresponding (sub-)component. It was found that the carbon biomass of beech was mainly distributed in the trunk (at least $51 \%$ ), then in the branches and then in the roots. The proportion in the wood of branches with diameters greater than $4 \mathrm{~cm}$ increased rapidly during the rotation. If the roots were not taken into account, the distribution of the aerial carbon biomass between the trunk and the branches was respectively $75 \%$ and 
$25 \%$ in the 81 -year-old stage, and $58 \%$ and $42 \%$ in the 145 year-old stage. In comparison, in an 80 -year-old stand it was found that beech contained as much carbon in its branches as in the trunk [34]. In a 69-year-old pine stand, $82 \%$ of the aerial carbon was stored in the trunk and $15 \%$ in the branches [14].

\subsection{Forest exploitation during a stand rotation}

Biomass sampling, with detailed component data in a time sequence, is of interest because it is possible to forecast the future of the wood after thinning and the clear felling, both qualitatively and quantitatively. Under the present management regime in the Fougères beech forest, including thinning and the clear felling within one stand rotation: (1) remnants left on the ground, would consist of $32 \mathrm{t} / \mathrm{ha}$ (16 t/ha of carbon) of wood with diameters less than $1 \mathrm{~cm}$, and $75 \mathrm{t} / \mathrm{ha}$ (36 t/ha of carbon) of wood between 1 and $4 \mathrm{~cm}$ diameter; (2) quantities of 4 to $7 \mathrm{~cm}$ fire wood exported would be $120 \mathrm{t} / \mathrm{ha}$, i.e. $57 \mathrm{t} / \mathrm{ha}$ of carbon, and $629 \mathrm{t} / \mathrm{ha}$ of industrial wood greater than $7 \mathrm{~cm}$, i.e. $298 \mathrm{t} / \mathrm{ha}$ of carbon; (3) the quantity of roots left in the soil would be $134 \mathrm{t} / \mathrm{ha}$, i.e. $65 \mathrm{t} / \mathrm{ha}$ of carbon.

Our study did not take standing dead wood into account. During the rotation, the forester systematically felled dead or dying trees during the normal or sanitary thinning process. Consequently, this carbon is not exported and remains in the stand. It is the same pattern for the dead branches and coarse roots on living trees.

All dead wood left on the ground contribute to a pool of stored carbon which decomposes, liberating $\mathrm{CO}_{2}$, producing humus and acting as an energy source for the development of soil fauna and flora. The same is true for the roots. Decomposition rates vary depending on the material (chemical quality, diameter etc.) and the environmental conditions. According to Silver and Miya [32], the chemical composition of the roots is the primary factor controlling root decomposition, and climate and environmental factors are only secondary.

The exported wood may be used in various ways: for firewood, paper, planks, construction or furniture. The majority of the carbon stored in the trees is exported from the forest ecosystem but, part of the carbon remains stored temporarily in the exported wood for some years before being released into the atmosphere as $\mathrm{CO}_{2}$, and the rest of the wood exported is used as fuel. In comparison with fossil fuels, wood burning causes less damage to the environment [27].

In this study we have not simulated all the different types of management, notably a reduction in the length of the forest rotation. However, this work provides a data base for future models. With this in mind, it would be useful to complete our sampling with an intermediate stage in the time sequence: a stand between 80 - and 145-years-old. The simulation of the changes in the processes of immobilisation of standing dry matter demonstrated a plateau between the 50- and the 80-year-old stages and the shape of the production table curves showed that this addition would be interesting [7].

\section{CONCLUSION}

As a result of this work, we have managed to achieve the original objectives. The work has provided a detailed database, of total and sub-divided dry matter and carbon biomass, of Atlantic lowland beech, during a forest rotation, at the stand scale. Such a database could be used to provide a more accurate determination of carbon biomass stocks at the forest massif or even the regional scale. The data will also be useful to improve our knowledge about the quantitative and qualitative future of the carbon stocks in living beech, during one rotation. In addition, the mineral element levels in the different samples were analysed. Thus, the data on dry matter combined with mineral element levels will provide a more accurate determination of losses from the forest ecosystem, and the returns of nutrients into the soil, at the stand scale and during a forest rotation, depending on the forest exploitation.

Acknowledgements: We would like to thank the Office National des Forêts and the GIP-ECOFOR for financial help in setting up the experimental site; the STIR-ONF-Orléans for the forest inventories; the University of Rennes-1; the INRA - Centre de Nancy team and in particular Serge Didier and Christian Hossann for the sampling and analyses.

\section{REFERENCES}

[1] Becker M., Picard J.F., Timbal J., La forêt, Masson, Paris, 1981.

[2] Cannell M.G.R., World forest and primary production data, 1982.

[3] Cannell M.G.R., Forests, Kyoto and climate, Outlook Agric. 28 (1999) 171-177.

[4] Clément B., Gloaguen J.C., Touffet J., Contribution à l'étude phytosociologique des forêts de Bretagne, in : Gehu J.M., Colloques phytosociologiques. III - La végétation des forêts caducifoliées acidiphiles, 1974, Lille, Cramer J. (Ed.), Vaduz, 1975, pp. 53-72.

[5] Cole D.W., Van Miegroet H., Chronosequences: a technique to assess ecosystem dynamics, in: Dyck W.J., Mees C.A. (Eds.), Research strategies for long-term site productivity, Forest Research Institute, New Zealand, 1989, pp. 5-23.

[6] Dagnelie P., Recherches sur la productivité des hêtraies d'Ardenne en relation avec les types phytosociologiques et les facteurs écologiques, Bull. Inst. Agron. Stat. Rech. Gembloux 25 (1957) 44-94.

[7] Décourt N., Tables de production pour les forêts françaises, ENGREF, Nancy, 1973.

[8] Deneux M., L'évaluation de l'ampleur des changements climatiques, de leurs causes et de leur impact prévisible sur la géographie de la France à l'horizon 2025, 2050 et 2100, Office parlementaire d'évaluation des choix scientifiques et technologiques, France, $\mathrm{N}^{\circ} 3603$ Assemblée Nationale, $\mathrm{N}^{\circ} 224$ Sénat, 2002.

[9] DERF, Les indicateurs de gestion durable des forêts françaises, Ministère de l'Agriculture et de la Pêche, 2000.

[10] Devillez F., Jain T.C., Marynen T., Structure et biomasse d'une hêtraie en Haute-Ardenne, Bull. Acad. Roy. Belg. (Classe des Sciences) 59 (1973) 303-331.

[11] Duvigneaud P., Kestemont P., Timperman J., Moniquet J.C., La hêtraie ardennaise à Festuca altissima à Mirwart - Biomasse et productivité primaire, in: Duvigneaud P., Kestemont P. (Eds.), Productivité biologique en Belgique, SCOPE, Travaux de la section belge du programme biologique international, Duclot, Paris-Gembloux, 1977, pp. 107-154.

[12] Granier A., Ceschia E., Damesin C., Dufrêne E., Epron D., Gross P., Lebaube S., Le Dantec V., Le Goff N., Lemoine D., Lucot E. Ottorini J.M., Pontailler J.Y., Saugier B., The carbon balance of a young beech forest, Funct. Ecol. 14 (2000) 312-325.

[13] Hossann C., Vérification de la qualité du système et des solutions gravitaires dans la phase initiale. Chronoséquence du site atelier de Fougères, D.E.A. Nat. Sciences du Sol, Université H. PoincaréNancy 1, 1999. 
[14] Janssens I.A., Sampson D.A., Cermark J., Meiresonne L., Riguzzi F., Overloop S., Ceulemans R., Above- and belowground phytomass and carbon storage in a Belgian Scots pine stand, Ann. For. Sci. 56 (1999) 81-90

[15] Joucla V., Gourier J., Les arbres de nos forêts. Les principales essences des forêts françaises dans leur milieu, ONF, Paris, 1996.

[16] Kimmins J.P., Mailly D., Seely B., Modeling forest ecosystem net primary production: The hybrid simulation approach used in FORECAST, Ecol. Model. 122 (1999) 195-224.

[17] Koerper G.J., Richardson C.J., Biomass and net annual primary production regressions for Populus grandidentata on three sites in northern lower Michigan, Can. J. Forest Res. 10 (1980) 92-101.

[18] Kurz W.A., Apps M.J., A 70-year retrospective analysis of carbon fluxes in the canadian forest sector, Ecol. Appl. 9 (1999) 526-547.

[19] Lebret M., Nys C., Forgeard F., Litter production in an Atlantic beech (Fagus sylvatica L.) time sequence, Ann. For. Sci. 58 (2001) 755-768.

[20] Le Goff N., Ottorini J.M., Root biomass and biomass increment in a beech (Fagus sylvatica L.) stand in North-East France, Ann. For. Sci. 58 (2001) 1-13.

[21] Lemée G., La hêtraie naturelle de Fontainebleau, in: Lamotte M., Bourlière F. (Eds.), Problèmes d'écologie : Écosystèmes terrestres, Masson, Paris, 1978, pp. 75-128.

[22] Liu J., Peng C., Apps M., Dang Q., Banfield E., Kurz W., Historic carbon budgets of Ontario's forest ecosystems, For. Ecol. Manage. 169 (2002) 103-114.

[23] Malhi Y., Baldocchi D.D., Jarvis P.G., The carbon balance of tropical, temperate and boreal forests, Plant Cell Environ. 22 (1999) 715-740.

[24] Millier C., Nys C., Ranger J., L'échantillonnage dans l'étude de la minéralomasse forestière : l'exemple des taillis ardennais, Ann. Sci. For. 43 (1986) 165-178.

[25] Müller-Starck G., Stark R., Inheritance of isoenzymes in European beech (Fagus Sylvatica L.), J. Hered. 84 (1993) 291-296.

[26] Nabuurs G.J., Päivinen R., Sikkema R., Mohren G.M.J., The role of European forests in the global carbon cycle - A review, Biomass Bioenergy 13 (1997) 345-358.
[27] Pandey D.N., Global climate change and carbon management in multifunctional forests, Curr. Sci. 83 (2002) 593-602.

[28] Ranger J., Cuirin G., Bouchon J., Colin M., Gelhaye D., Mohamed Ahamed D., Biomasse et minéralomasse d'une plantation d'épicéa commun (Picea abies Karst.) de forte production dans les Vosges (France), Ann. Sci. For. 49 (1992) 651-668.

[29] Ranger J., Marques R., Colin-Belgrand M., Flammang N., Gelhaye D., The dynamics of biomass and nutrient accumulation in a Douglas-fir (Pseudotsuga menziesii Franco) stand studied using a chronosequence approach, For. Ecol. Manage. 72 (1995) 167-183.

[30] Röhrig E., Biomass and productivity, in: Röhrig E., Ulrich B. (Eds.), Ecosystems of the world. 7. Temperate deciduous forest, Elsevier, Amsterdam - London, New York, Tokyo, 1991, pp. 165-174.

[31] Seely B., Kimmins J.P., Welham C., Scoullar K., Defining standlevel sustainability, exploring stand-level stewardship, J. For. 97 (1999) 4-11.

[32] Silver W.L., Miya R.K., Global patterns in root decomposition: comparisons of climate and litter quality effects, Oecologia 129 (2001) 407-419.

[33] Toutain F., Étude du sol et des eaux de la forêt de Fougères (I.-etV.), Thèse de $3^{\mathrm{e}}$ cycle, Université Rennes I, 1965.

[34] Vande Walle I., Mussche S., Samson R., Lust N., Lemeur R., The above- and belowground carbon pools of two mixed deciduous forest stands located in East-Flanders (Belgium), Ann. For. Sci. 58 (2001) 507-517.

[35] Vysny J., Shvadchak I., Comps B., Gömöry D., Paule L., Genetic diversity and differentiation of beech populations (Fagus sylvatica L.) in western Ukraine: the Ukrainian Carpathians and adjacent territories, Russ. J. Genet. 31 (1995) 1540-1551.

[36] Wang J.R., Zhong A.L., Kimmins J.P., Biomass estimation errors associated with the use of published regression equations of paper birch and trembling aspen, North. J. Appl. For. 19 (2002) 128-136.

[37] Yarie J., Viereck L., Van Cleve K., Dyrness C.T., The chronosequence as an aid to understanding the long-term consequences of management activities, in: Dyck W.J., Mees C.A. (Eds.), Research strategies for long-term site productivity, Forest Research Institute, New Zealand, 1989, pp. 25-38. 